
www.globaljournalseries.com; Info@globaljournalseries.com

\title{
SCIENCE AND MATHEMATICS EDUCATION AS TOOLS FOR DEVELOPING ENTREPRENEURSHIP SKILLS AMONG SECONDARY SCHOOL STUDENTS IN CROSS RIVER STATE, NIGERIA.
}

\section{OGBE ALPHONSUS OKORI AND OMENKA JERRY EBERE}

(Received 23, May 2019; Revision Accepted 24, July 2019)

\begin{abstract}
This paper examined the relevance of Basic Science, mathematics and technology as an important tool for developing entrepreneurship skills among upper Basic students in junior secondary schools in Cross River State of Nigeria. Due to lack of employment opportunities which has become a very serious issue in Nigeria today, the need for entrepreneurship skills to be inculcated in this students is very important especially at the upper Basic level where some of the students may not have the opportunity to further their education such students can use the skills which was inculcated into them to become an independent person who can now establish either a bee farm, can go into planting of flowers which in turn can be sold to provide money for him, poultry farm, snail farm, manufacturing of liquid soap, making of perfume, computer repairs and maintenance, construction of inverter. Employment of qualified teachers and improved method of teaching can go a long way in developing these skills in the students, it has been observed that lack of fund, qualified teachers and non existence of entrepreneurship club in our schools are some of the challenges that hinder the inculcation of entrepreneurship skills to our students. Adequate fund should be made available; awareness about inculcating such skills to our student should be created. Junior secondary school students should be taught on how to be self reliant and engaging in gainful ventures that can generate money for them. Every teacher teaching science, mathematics and technology should organize a field trip for the students as this will enable the students have first hand information and seeing things for themselves. It was concluded that Entrepreneurship has the potential of equipping individuals with skills that can help individuals to be self reliant even creates and generate employment for others.
\end{abstract}

\section{INTRODUCTION}

An entrepreneur is someone who has the ability to develop a new venture in business in order to make money, often in a way that involves financial risks (Quirk, 2003) According to Agbodu in Ezema (2000), an entrepreneur is defined as the owner of a business who is responsible for the initiation and organization of the enterprises out of a desire to maximize profits.
An entrepreneur is therefore a person that has developed certain skills, attitudes and behavior that enable the person to establish a business, thereby creating job for himself and others. Entrepreneurs are innovators who are capable of developing new technologies, new product and service adapting existing technologies to new use. In the word of Inegbenebor (2006) Entrepreneurship raises the level of productivity in the economy by harnessing and utilizing

Ogbe Alphonsus Okori, Department of Science Education University of Calabar Omenka Jerry Ebere, Department of Curriculum and Teaching Benue State University, Makurdi 
resources efficiently.

Entrepreneurship education is the education that provides training experiences and skills that are suitable for entrepreneurial endeavour (Ovie 2011). According to Ezema (2000) Entrepreneurship education is the education given to an individual which will help him develop the skills needed for the management of any business venture. This type of education helps the person to take financial risk and at the same time utilize the material and human resources available to him to achieve the aim of establishing the business. In another development Ezema (2008) and Omofio (2008) all describe entrepreneurship education as a process of providing individual with the ability to recognize commercial opportunities and the insight, self esteem, knowledge and skills to act on them.

Entrepreneurship Education hence prepares secondary school leavers and dropout with entrepreneurial knowledge and inculcates in them skills that are socially useable. It produces self-reliant secondary school leavers and school dropout who can utilize the skills they have acquired to established personal businesses.

Nowadays entrepreneurship has become a global and unavoidable issue. The idea of becoming an entrepreneur is more and more attractive to students, because it is seen as a valuable way of participating in the labour market without losing one's independence (Martinez et al 2007) as cited in Aurora (2008). In the view of Rinji (2013) entrepreneurship education has become important issue in the life of Nigerians and institutions of learning. Therefore secondary schools, polytechnic, Colleges of Education and Universities have seen the need to include entrepreneurship education in the curriculum. The federal government is advocating that entrepreneurship education be made popular and fostered among business and non business students at all levels of education. This is because acquiring entrepreneurship skills will help to develop the youth, student and even the teachers socially, politically and economically. Researchers such as Brase and Runge (2014) accepted that entrepreneurial behavior remains a crucial engine of innovation and growth for the national and individual companies, for Nigeria to be at par with the developed countries of the world there is the need to make science and mathematics more interesting to the citizenry and ensure effective teaching of science in our schools (Obinaju 2010) in (Arokoyo and Ugonwa
2012). Hence developing entrepreneurship skills in student will enhance increase and interest of learners since it is practical based on learner centered this confirm a Chinese proverb that says what I hear, I forget, what I see I remember and what I do I understand.

Science being a combination of biology, Chemistry, Physics and Mathematics has to be taught In such a way that students at the upper Basic School level will inculcate the skill of self reliant by teaching and laying more emphasis on the practical aspect of the subject by this the student can acquire entrepreneurship skills which can make them self reliant, with the teaching of Basic science using practical approach the student can acquire entrepreneurship skills which will make them self reliant even if they do not proceed to the senior secondary school level. It is on these basis that this paper tends to examine basic science and mathematics as a tool for developing entrepreneurship skills in upper Basic school students under the following headings.

- Science and Mathematics as a tool for developing entrepreneurship skills in secondary school students through functional Chemistry Education

- Science and Mathematics as a tool for developing entrepreneurship skills in secondary school students through functional Biology Education.

- Science and Mathematics as a tool for developing entrepreneurial skill in secondary school through functional Physics Education.

- Science and Mathematics as a tool for developing entrepreneurship skills in secondary school students through functional Mathematics Education

Chemistry as part of the subject which combine with other science subjects to form basic science is an investigative science subject which deal with the procedures and processes of making thing which would serve as a medium through which the basic chemical knowledge and skills required by basic science students and youths who could not further their education after Upper Basic and those who will proceed to senior secondary to be employable are acquired, this is the reason why basic science has been acknowledged as the bed rock of national development according to Okori (2013). Chemistry contributes to quality of life and nation building in all aspects of science as noted by Festus and Ekpete (2012). Although Nigeria is rich in human and natural resources it is still one of the poorest and under developed countries of 
the world as noted by Nwachukwu (2009) in Matazu (2010). As a developing nation, Nigeria is filled with many graduate and secondary school dropout, the youths roaming about the streets in search of non existing white collar jobs. This is because most of our youth are not employable and it is contrary to the aims and objectives of Nigeria education, as contained in the national policy of education which stress the development of self-reliant nation. And also the goals of science education in Nigeria, among others are cultivating, knowing, inquiring and rational mind for the conduct of good life and democracy producing scientist for National development and providing understanding of the complexity of the physical world, the forms and the conduct of life (FRN 2004; 29) in Effiong and Okon (2012). This shows that the policies and practices in secondary schools and Universities have some wide gaps of forms Matazu (2010) in Okori (2013). Science and mathematics graduates ought to have acquired sufficient skills that would make them self-reliant prepared to enter into jobs and make progress. Science and Mathematics Education should prepare individual to be selfemployed in various enterprises, because as the backbone of all sciences, it is contextually versed with topics and concept that have so much to offer, its students and graduates should be trained for self employment. However Nigerians are currently facing employment related problems because science and Mathematics education has not been taught properly in the Universities and secondary schools to prepare both the students and graduates to function well in the nation undergoing transition from rural economy to modern economy (Okori 2015, Nwachukwu 2009). In the same vein many researchers lamented that the teaching of Science and Mathematics in Nigeria is not practically done as it ought to be, The practical aspect of Basic Science is relevant to the development of skills needed for entrepreneurial development and at the same time required for movement from Junior Secondary to Senior Secondary level. Most at times Basic Science education is taught theoretically because of lack of competent teachers or lack of equipments. Hence students and graduates without hands on skills and minds on experience. In another development Oriafo (2002) as cited by Matazu (2010) in Abdu (2014) argued that science and mathematics education including chemistry education in Nigeria is grossly characterized by inadequacy of content and ineffective methodology by teachers, paucity of facilities, equipment and materials in our laboratories as well as dominated socio cultural lapses, including the lack of a developed entrepreneurship skill training. These lapses 014 have to be properly tackled for our science education to produce individuals with sufficient skills for self-reliance. The present trends of mass unemployment of those who have acquired the junior secondary school certificates and graduates of basic science in Nigeria shows that science education in our secondary schools and universities are not preparing the Nigerian students and graduates at it ought to be. The Nigeria educational system is supposed to focus on the problems of its people particularly the youths.

Unemployment is the result of not only the limited job opportunities but also job seekers incapability of meeting the requirements and qualifications required by the business sector. Therefore, every job seeker needs to be equipped with certain knowledge or skills and attitude.

The attitudes needed by anyone intending to become an entrepreneur and a job seekers are entrepreneur attitudes. In view of the above mention condition science education, particularly integrated science education is expected to equip students both the secondary school and the university level for self reliance. Enough is enough, days have come when science and mathematics teachers teaching science particularly the chemistry aspect should be more efficient, creative, resourceful, innovative, industrious and more patient to make teaching of this important and lucrative subject more meaningful relevant and interesting to the learners. Teachers are to teach the chemistry aspect of science to learners in a manner, they can even create jobs for themselves and others. If they are not able to proceed to the senior secondary school level and this will make them self reliance, instead of going about searching for jobs. They create jobs for themselves and others. Hence the teaching and learning of the chemistry aspect of basic science for skill acquisition is considered not "merely a necessity but a matter of survival" teaching and learning of the chemistry aspect science and mathematics for skill acquisition is a panacea to unemployment. According to Adeyemo (2009) entrepreneurial skills are basic skills necessary to enable an individual start, develop, finance and succeed in his/her home enterprise. In the same vein Ogalanya (2009) posits that for some decades now emphasis had shifted from teaching science for acquisition of knowledge to the teaching for 
skills acquisition which for sure will lead to functional effective living skill acquisition would be possible when practical approaches are used in lesson delivery rather than conventional methods.

Entrepreneurship, according to Hisrich in Lankford (2003) as cited in Abdu (2010) is the "process of creating something different with value by devoting the necessary time and assuming the accompanying financial psychic and social risks and receiving the resulting reward of most personal satisfaction". It is about self reliance, which involves identification of a market and mobilizing necessary resources to serve that market through a business outfit. It is essentially about someone creating a market from his own resource.

Entrepreneurship education in basic science through the chemistry aspect in particular will help to redirect the minds of youths towards world of business and independence, increase innovative and creative spirit thereby increasing the number of employers, than employee as well as ensuring stable national growth, development and sustainability. Denga (1993) in Uduma (2009) describe education as intellectual yeast that ferments all spheres of national development. Skill development is synonymous with the best mode of science learning that is learning by doing, for it is only by practice that skills in doing things develop in individuals. It is however sad to observe that both at the secondary and the university level of education, youth find themselves in an environment not fully prepared for teaching and learning practical skills. Due to lack of adequate teaching and learning facilities and especially the lack of entrepreneurship training. This is the reason why a Nigerian science students and graduates cannot stand out proudly and announce to the whole world that the Nigerian class has taught him/her how to be on his/her own after graduation but on the contrary Coyert (2012) from the University Washington said "the class has taught me how one can successfully create one's own job, a skill that is very worthwhile in today's uncertain times".

It is only by doing science (Basic Science) practically, since it is practical oriented and teaching practically for the purpose of entrepreneurship that will ultimately promote employability of Nigerian youths. Entrepreneurship training will help the youths develop skills that will make them self - reliance in life. It is only through these training that Nigerian youths can successfully create jobs for themselves and others. In the same vein Omosewo and Akanun (2013) pointed out the need for introducing entrepreneurship education in Nigeria educational system can be easily be attributed to scary unemployment statics of the nation.

The production of paints, package water production, perfume production, soap production and even treatment of water or water purification should be taught to the students at the junior secondary school level as part of developing entrepreneurship skills in them for self actualization and reliance.

The entrepreneur is widely regarded as an integral player in the business culture of any nation and particularly as an engine for job creation and economic growth, Biology as an applied field of study is diversified in nature and capable of providing job opportunities for those who studied it.

Biology is commonly known as the study of life, this means the study of life in totality. In other words, Biology is a natural science which studies living organisms and how they interact with each other in their environment. It examines structure, functional growth, origin, evolution and distribution of living things. There are four unifying principles from the foundation of modern Biology. There are cell theory, evolution, genetics and homeostasis. Biology is taught as an important part of basic science as a subject taught in the university and secondary schools around the world (Pascal, 2007). Biology which is the science of life makes life enjoyable and occupies a unique position in Nigeria curriculum. Biology is taught in primary and junior secondary school as basic science.

Research is being carried out in the field of Biology. It is pertinent to know that a series of professions that are of vital importance to man especially human and veterinary medicine, agriculture, breweries and food industrials make use of basic science through Biological principles at the junior secondary school level. Abubakar (2009) asserted that the influence of biological science is more likely to have a more significant effect on man than the physical sciences. This is because most of our basic problems are biological. Therefore proper understanding of life processes would lead to greater appreciation with the living world. The understanding is an important force in the realization of a healthy protective and happy life which is the ultimate goal of education.

Biology contributes to the realization of the ultimate goals of education. This is dependent on 
how it is taught. When it is properly taught using activity-based instruction such as inquiry method. This stands to contribute immensely to general development of the students. To achieve this, the teachers in secondary schools should do everything humanly possible to produce students devoid of parasitizing the nation's economy. This can be achieved by guiding the students to realize that it is $100 \%$ better to be innovative, creative self-reliant, entrepreneurial and productive than being dependent on government for employment and other essential of life. But biology education had not actually achieved this due to the way it is presented to the students. This aspect of the paper deals with the issue of biology as an aspect of basic science in developing entrepreneurship skills in junior secondary school students.

\section{ADVANTAGES OF ENTREPRENEURSHIP EDUCATION}

Bolariwa in Ezeudu (2008) listed the following as an advantage of entrepreneurship education.

- It helps the student to form a base of knowledge and operation of business and develop some level of familiarity and comfort with the business environment such as technological changes, micro entrepreneur e.t.c

- It plays a complimentary role in developing the occupational acknowledgement, job skills and work experiences.

- It offers opportunities to students for job experience and earning, saving and investing money at earlier stage of living than their peers, contributing to their abilities and their sense of self worth.

- There would be great reduction in the rate of unemployment in our society, self employment and business ownership will become viable and appealing goals for today's students.

To achieve these STM more especially biology curriculum should be made adaptable, stimulation and relevant to needs of the student and the society at large.

Biology education is defined as the acquisition of education principals and knowledge in solving biological problems. Entrepreneurship biology education can now be described as the education that provides employment opportunities for biology graduates and junior secondary school leavers through basic science. It is the education that will empower biology graduates and secondary school leavers for the application of biology knowledge and skills acquired in solving the problem of unemployment for oneself and others this will increase the income generation capacity of biology graduates and junior secondary school leavers.

Unemployment is one of the problems facing the Nigeria society as every year, large number of graduate are produced from secondary and tertiary institution in Nigeria. Unemployment arises where able bodied and willing persons who are qualified and capable for job at a given wage do not find the employment opportunities to do the job (Iwumadi \& Oforegbu, 2011). Employment is therefore when an able bodied individuals has gained wage able job either employed by self or government in order to solve the problem of graduates unemployment in biology and basic science there is need to key in the new dynamics of education through lifelong learning biology and basic science.

Biology is an applied field of study built upon many disciplines for the purpose of achieving and maintaining the well being of individuals in an ever changing society. Biology curriculum aims broadly at developing life coping skills such as recording, measuring, communicating, observing, predicting, hypothesizing, inferring among others. These skills when acquired are useful for success in business and for problem solving and adaptation for national and individual development. Thus the inculcation of these skills into the students will enable $t$ hem on graduating to become self reliant and productive citizens without waiting for government employment. The teaching of Biology through basic sciences at the junior secondary school, and biology itself at the senior secondary level even in the university also helps to develop in learners scientific attitude such as open mindedness, patience, curiosity, honesty and objectivity.

Furthermore biology offers a lot of opportunity in various subjects which can be taught for entrepreneurship ability among the students. These subjects will depend on the geographical locations and their biodiversity for the obvious reason that a student living far away from the sea need not be taught sea weed farming.

These areas according to Nayah (2002) include:

- Agriculture or Bee Keeping: it includes the preparation of an artificial hire to attract the honey bee and once they colonize honey can be extracted as when required, the other products include bee wax.

- Aquaculture: this includes fish farming prawn farming and crab culture. 
- Sea weed culture: this includes intensive sea weed farming. Product includes agar, Agarose, machine thickening agents.

- Floriculture: growing flowers for ornamental values and for export as well as domestic market.

- Horticulture: growing fruits and vegetable, the product can be exported as well domestic market.

- Ecotourism: this is the most developing field where the students will be able to guide the tourist both foreign and domestic to show them the bio-diversity.

- $\quad$ This again is a lucrative business with export market.

- Mushroom culture: it is a source of protein and has good export market value.

- Water conservation: water is a must in many nations of Africa for agricultural and drinking.

- Preservation of soil fertility and spreading of the desert, biological methods are having advantage over the others.

- Poultry: Rearing birds for eggs and human consumption.

- Insect pest and their control: to increase agricultural yield.

These areas among others when properly practiced can increase the economic growth rate of Nigeria because of the export market potential thereby creating employment. This will also improve the life of those who cannot proceed for higher education. However it is the duty of the basic science and biology teachers to teach these entrepreneurial topics or areas properly. For the basic science and biology teachers to inculcate entrepreneurship skill in students demand that he/she in addition to being the master of the subject will be able to spur the students' interest in the subject through his or her method of teaching and attitude to the subject.

According to Ukeje in Ezema (2000) a good teacher is one who in addition to transmitting knowledge and effective manner is also able to inspire the students to greater height of achievement by guiding them to the full realization of their potentials.

Since unemployment is on the increase, there is need for re-orientation of the youth to pay attention to skill oriented subject and topics like basic science and biology. This will help the student to acquire the competencies required for employment and productivity. This basic science and biology teachers should employ child centered method in teaching for the acquisition of entrepreneurship skills in basic science and biology, so that the students will be able to stands on their own after graduation.

Physics is an aspect of physical science that has to do with the measurement and determination of accuracy. Physics is a part of the basic science which has to inculcate the skill of measurement and accuracy into the student through careful observations and through this it can be useful to both the students, teachers, graduate of physics and basic science and even the entire nation, it is in this not that this aspect of the paper takes a look at physics as tool for developing entrepreneurship skills at junior secondary school level.

The study of physics at all levels even at the Secondary as science is crucial for any nation that wants to maintain its lead among the committee of nation. In fact the technological potentials of any nation could be more accurately gauged by the quality of its physics education for without physics the technological culture of her citizens cannot be firmly rooted. (Utibe \& Agah, 2014). The scientific study of matter and energy and how they interact with each other is referred to as physics. Physics emerge in research which include a wide range physical phenomena in many branches of physics spanning all length scales: from sub atomic particles of which all ordinary matter is made (Particles physics) to the behavior of material universe as a whole. They utilized scientific methods to formulate and test hypothesis that are based on observation of the natural world (Usman, 2012). The goals of physics in this regard is to use the result of these experiments to formulate scientific laws usually expressed in the language of mathematics, which can then be use to predict other phenomena (Ogunleye 1991)

Physics from career perspectives share some similitude with the entrepreneurship from the view point of the definition of physics, it generally can be said that trained physicists apply their skills to engineering, computing and finance, employing entrepreneurial principles. The diversity of career development in physics has made some physicists take up additional career where their knowledge can be combined with further training in other disciplines such as patent law in industry or private practices. (Owolabi Akintaye and Adeyemo, 2011).

Training opportunities abound for graduate of physics. A physics graduate can venture into the field of engineering such graduate are qualified for post diploma (PGD) in petroleum, electrical electronics, computer science or computer engineering other training opportunities includes 
,masters of Business Administration (MBA) and Master of Public Administration (MPA) the interconnectedness between physics and mathematics has lured physics education graduates to professional examinations such as Chartered Institute of Bankers (CIB) and Association of Certified Chartered Accountant (ACCA) as observed by Bruyat and Julien (2000). Several opportunities abound for physicists in entrepreneurial development, few of which include transportation, Aviation, Medicine Industry warfare, peace, entertainment and electrification among others (Utibe and Agah). However areas of Calendar and entertainment development in any field of engineering Geophysics which generally involved undertaking science exploration and producing controlled source sciences data by creating a picture of What lies below the earth's surface; metallurgy concerned with the extraction and processing of various metals; Radiation Protection Practitioner Specialization, giving advice and guidance about the possible hazard of ionizing radiation, such as $\mathrm{X}$-rays as well as radioactive materials and waste.

Other career opportunities in entrepreneurial physics include seismic interpreter which involves sending pulses of sound energy down through layers of rock beneath the earth's surface as observed by Owolable et al. institutional teachers that offers to teach curriculum subjects, meterologist who study the causes of particular weather conditions using information obtained from the land, sea and upper atmosphere and several other related professional development opportunities.

The importance of physics as a requirement for entrepreneurship development of any nation cannot be over emphasized, however, Nigeria as a nation with developing economy has suffered appreciably from high rate of unemployment, inconsistent power supply, inadequate food and water supply poor medical care, as well as high corruption cases compiled with un-conductive working and living environment which predicated on low level of scientific and entrepreneurial development concerted effort made at tackling some of these menace was channeled to producing scientists at various level; especially in physics for national and entrepreneurial development for instance, the federal government of Nigeria through the Federal Ministry of Education in 2008 reviewed the physics curriculum physics in line with MDGS and NEEDS Despite the above effort Nigeria Government is still seen as the provider of employment to the teeming population of over 160 million.

Mathematics has always been recognized as the basic intellectual instrument for science and technology and has actually become the essence of scientific thought in everyday life. This much importance is evident when mathematics is made a compulsory subject in the Nigeria Educational system.(FRN,2004).This is obvious because of its importance to natural scientific and technological development (lyekekpolor, 2005).

Functional mathematics is the mathematics that will develop entrepreneurship skills in the students. A functional mathematics education should equip the younger generation with skills and knowledge considered necessary for them to function effectively and contribute to the overall development of the society. A functional Mathematics Education according to abdul (2005) is the whole some training of an individual that makes him or her useful to himself, the community and the nation as a whole. Functional mathematics Education is the education that works and can be applied on the sport to solve immediate problems of the individual with the requisites skills and knowledge to function maximally in the society in which there belongs. It is a pre-requisite for social change and meaning national development.

For mathematics education to be functional it should be relevant to the needs of the society and education not only to train high level manpower but contributes to the overall development of the nation. A functional mathematics education should promote the welfare of its citizenry, advance $s$ in science and technology and economic growth, because education is a pivot on which other sectors revolve. Furthermore, functional mathematics education should translate into the establishment of improved infrastructures such as road, electricity,, health facilities, water supply, integrated rural development, poverty reduction, reduction of unemployment, reduction in crime and increase in economic growth (Abdul,2005).

\section{Strategies Required for Promoting Entrepreneurship in Science and Mathematics Education.}

The following strategies will assist in promoting entrepreneurship in basic science education

- Employment of qualified and competent basic science teachers, Biology and mathematics teachers should be competent and qualified in terms of professional and potential skills and knowledge of business opportunity available in 
basic science: The teachers is expected to know both the methodology and content of the subject matter in order to foster effective teaching and learning.

- Teaching strategies: Basic science and mathematics teachers should use appropriate teaching strategies such as field trips demonstration and inquiry in teaching entrepreneurship education so that students will understand the lesson.

- Entrepreneurship club and exhibition: entrepreneurship club and exhibition should be established to promote and teach those topics in basic science that create self employment.

- Seminars and workshops: Seminars and workshops on entrepreneurship in basic science are needed by the entrepreneur to succeed in business. So seminars and workshop should be organized for students at least once each academic session. The successful entrepreneur and expert in basic science and other science subjects should be invited to deliver lecture on entrepreneurship to broaden the students mind so as to learn about entrepreneurship.

- Curriculum Reform: Curriculum reform are needed to reposition the content to reality, there should be a review of the mathematics curriculum every five years for primary and secondary schools, this is because new contents are added and those obsolete and irrelevant aspect are can be dropped according to the needs of the time. Mathematics curriculum should be looked at in terms of its usefulness, control, development in terms of its products. In perspective, relevance means of what meets the interest, needs and abilities of a particular people and nation. In this context of reality, relevance can also be seen on the basis of competitiveness rather than isolation. Therefore if we are developing mathematics curriculum, the content, the method of instruction, the process of instruction as well as the philosophy of instruction must be those needed by the people.

\section{Challenges to Entrepreneurship in Science and Mathematics Education}

Entrepreneurship in Science (Biology, Chemistry and Physics)and mathematics are faced with a lot of challenges which includes:

- Lack of fund

- Assessment procedure

- Large classes

- Lack of awareness.

\section{CONCLUSION}

Entrepreneurship has the potential of equipping individuals with skills that can help in developing individuals to be self reliant even creates and generate employment for others. Junior secondary school levers should be taught on how to be self reliance and engaging in gainful ventures that can generates income for them. These can make the individuals to depend on him or IJher even if he or she does not further anymore. so the issue of entrepreneurship at this level should be taken serious and teachers teaching this subject should put in their best in trying to Inculcate this entrepreneurial skills into the students.

\section{RECOMMENDATION}

1. An entrepreneurship club (mushroom farming, bee farming, horticulture and floriculture) should be organized and encourage in basic science and biology education department.

2. Teachers should organize field trip for the students, this is to enable them get first hand information and seeing things for themselves e.g a visit to soap, cream, honey 3. packaging cake baking factories, bee farms and horticulture site e.t.c.

4. Government should provide fund which will be used in purchasing materials or establishing of farms that will be used for practical purposes

5. Both the federal, State government and private organization should employ qualified basic science and mathematics teachers and the existing ones who have been working for years should be made to attend workshop and seminars on new development in basic science, mathematics and others science related discipline.

\section{EDUCATIONAL IMPLICATION}

1. Students will be inculcated with the skills that will make them self reliance through entrepreneurship training.

2. Basic and practical skills will be taught to the students on the making and construction of inverter, soap making solving world problems, mushroom, fish, poultry and bee farming

3. It will help to promote teaching and learning as the students are shown the steps and procedure in the construction of various farms and inverters. 


\section{REFERENCE}

Abubakar, A., 2009 the place of teaching aid in classroom situation, November $24^{\text {th }}$ Guardian Newspaper, 8.

Abdu B., 2014. Chemistry Education and Entrepreneurial development in Nigeria Issues and challenges. Department of Chemistry Federal College of Education Katsina.

Abdu, B., 2010, Toward qualitative Chemistry Education for promoting Entrepreneurship for sustainable development Journal of quality education Isah Kaita College of Education Dutsinma 1 (1):27.

Abdu, A., 2005. Functional secondary education for self reliance: The way forward Multidisciplinary journal of research development 5 (1) 101-108.

Adeyemo S. A., 2009. Understanding and acquisition of entrepreneurial skill: a Pedagogical re-orientation of classroom teacher in science education. Journal of Turkish science education Vol. 6, ISSUE 3, December, 2009.

Akani, O. and Abonyi, O.S., 2013 Evaluation of chemistry textbooks use in Nigerian Secondary schools.

Arokoyo, A,A. and Nna, P.J., 2012. Creativity and process skills for self-reliance using Demonstration Approach of teaching Chemistry. Department of Curriculum Studies and Educational Technology, University of Port-Harcourt, Nigeria. http//:www.e journal of science.org. ARPN Journal of Science and Technology. Vol. 2 No. 11, December, 2012.

Arokoyo, A.A. and Ugonwa R.C., 2012. Assessment of resources availability for Chemistry instruction in the secondary schools in Rivers state. Journal of Emerging Trends in Educational Research and policy studies (JETER APS) 3(3): 346-357.

Aurora, A. C., 2008. Entrepreneurial potential in chemistry and pharmacy. Results from a
Large

survey.

File//c:/user/desktop/business chemistry journal of business Chemistry.

Bruyat, C and Julien, P. A., 2000. Defining the field of research in entrepreneurship, Journal of business venturing 16, 165 180

Cogert 2012 Cheme's Entrepreneurial Spirit. Chemical Engineering. University of Washington Catalyst

Effiong U.M and Okon E. N., 2012. Resources for chemistry teaching in secondary Schools in Akwa lbom state, Nigeria. An international Journal of science and Technology Bahir Dar, Ethiopia Voll (1) January- March, 2012:131-143 ISSN: 2225-8612.

Entrepreneurship development using physics Education International Journal EN Res. 2-6

Ezema, P. C., 2000; inculcation of entrepreneurial skill in students: A challenges to home Economics Teachers. A conference paper presented at the $5^{\text {th }}$ National Conference of women in college of education at F.C.E Akoka Lagos Between $9^{\text {th }}-1^{\text {st }}$ October, 2000.

Ezendu, F. O., 2008. Restructuring our science, Technology and mathematics (STM) Education for Entrepreneurship proceedings of science teachers Association of Nigeria.

Federal Ministry of Education Senior Secondary Education Curriculum Chemistry for SSI3. Nigerian Educational Research and Development Council (NERDC) 2007 Abuja, Nigeria. Website: www.nerdenigeria.org.

Federal Republic of Nigeria 2004, National Method Lagos: NERDC

Federal Republic of Nigeria 2004 National Policy on Education, Lagos, federal Government press.

Festus, C and Ekpete O. A., 2012 improving students performance and attitudes towards Chemistry through problem- 
based-solving techniques. International Journals of Academic research in progressive Education and development January 2012 vol 1, No 1.

Iwamachi, F.N and Ofoegbu, J., 2011. Promoting self reliance among secondary schools Students through entrepreneurial skills Academic scholarship Journal 3(I), 4855.

lyekekpor, S. A., 2005 Effect of computer assisted instruction on male and female Students achievement in mathematics, unpublished M.Ed dissertation, Benue state University, makurdi.

Matazu, S. S., 2010. The Relevance of Science, Technology and Mathematics Education (STME) in developing skills for selfreliance: the Nigerian experience. African Journal of Teacher Education 1(1). 223225.

Nayak, R., 2003. Teaching Commercial aspect of biology; $43^{\text {rd }}$ proceeding of STAN. HEBN 2009-201.

Obi N.C and Amba N. H., 2013 A chemistry class whfa kitchen resources and students Entrepreneurial ability.

Obiajulu, E. C., 2014 Towards effective integration of integration of creativity in Science educations for cooperative learning strategy. STAM 55 Annual Conference 2014.

Odili, G. A., 2006. Mathematics in Nigeria $\mathrm{Nn}$ Secondary Schools, Port harcourt.

Ogunleye, A. O., 1999. Science Education in Nigeria; Progress and problems, of science Education in Nigeria. Lagos at Sunshine International Publisher.

Ogalanya, G. O., 2009. Identifying the skills for entrepreneurship education in Vocational technical education paper published in entrepreneur practices in

Education, (ed) Dr. NPM Esomonu published Ti Umunze, Anambra State. Steinhoff, D and Burgress J.F Small Business Management Fundamentals 6 New York MC Graw. Hill Inc.
Okori, A. O., 2015.Science education development in Nigeria-seminar paper presentation, University of Agriculture, Makurdi, Benue State.

Omiofo, C. N., 2008 Curriculum and gender equity in entrepreneurial Education. Science Is fun A publication of STAN Edo state Branch $5^{\text {th }}$ ed 17-20.

Omosewo, O and Akanmu M. A., 2013. Evolution of functional basic and senior Secondary education curriculum in Nigeria: implications for effective Implementation.

Ovie, R. A., 2011. The Relevance of STMB Education in the development of skills and Women employment. Academic scholarship Journal 3(i), 179-183.

Owolabi, T. Akintoye, O.H and Adeyemo's. A., 2011. Career prospect in physics Education un a quest towards entrepreneurial skill development research Journal of Social science Vol. I(6), 1-5. ISSN 1815- 9125.

OSGF 2014, Transforming Nigeria: The reforms and results of the president 2010-2013. Published 2014 by the office of the secretary to the government of the Federation.

Pascale, H., 2007. the importance of science in modern society. New Jersey Prentise hall. Upper saddle River 22

Quirk, R., 2003. Longman dictionary of contemporary English. England Pearson Education Limited.

Rinji, D. G., 2013, the use of information and communication technologies (ICTS) for Entrepreneurship education for youth empowerment" in Nigeria/ the international Journal of education studies (IJES) 1(3), July, 2013

Runge, W and Brase, S., 2014. Education in chemical Entrepreneurship: toward Technology entrepreneurship for and in chemistry-related enterprises. RISCnet Germany and institute of organic chemistry, university of karisrune $\mathrm{TH}$ and KIT Germany. 
Susianna N., 2011. The chemistry teaching program for developing the senior High school Students entrepreneurial attitudes.

Udofia, T and Ekong, A. O., 2014 Cocoyam: An Improvised Resourced for Enhancing Creativity in teaching and learning of chemistry agricultural science. Science Teachers Association of Nigeria, Stem Education and Creativity 55 Annual Conference.

Uduma, M.K, Ellah, B.E. Ebi; B.O. and Ayengi F. A., 2009. Quality control in vocation and technical education for sustainable development in Nigeria: Vocational Technical teacher education programme in focus unpublished paper presented at the Educational conference. School of education. Isah Kaitu College of Education Dussinma.

Usman, S. I., 2012. Entrepreneurial and functional physic Education as a means of Achieving the National Objectives of Vision 2020 in Nigeria; Challenges and the Way forward physics education Unit, Department of Science and Technology Education, faculty of Education, University of Jos, Nigeria. 